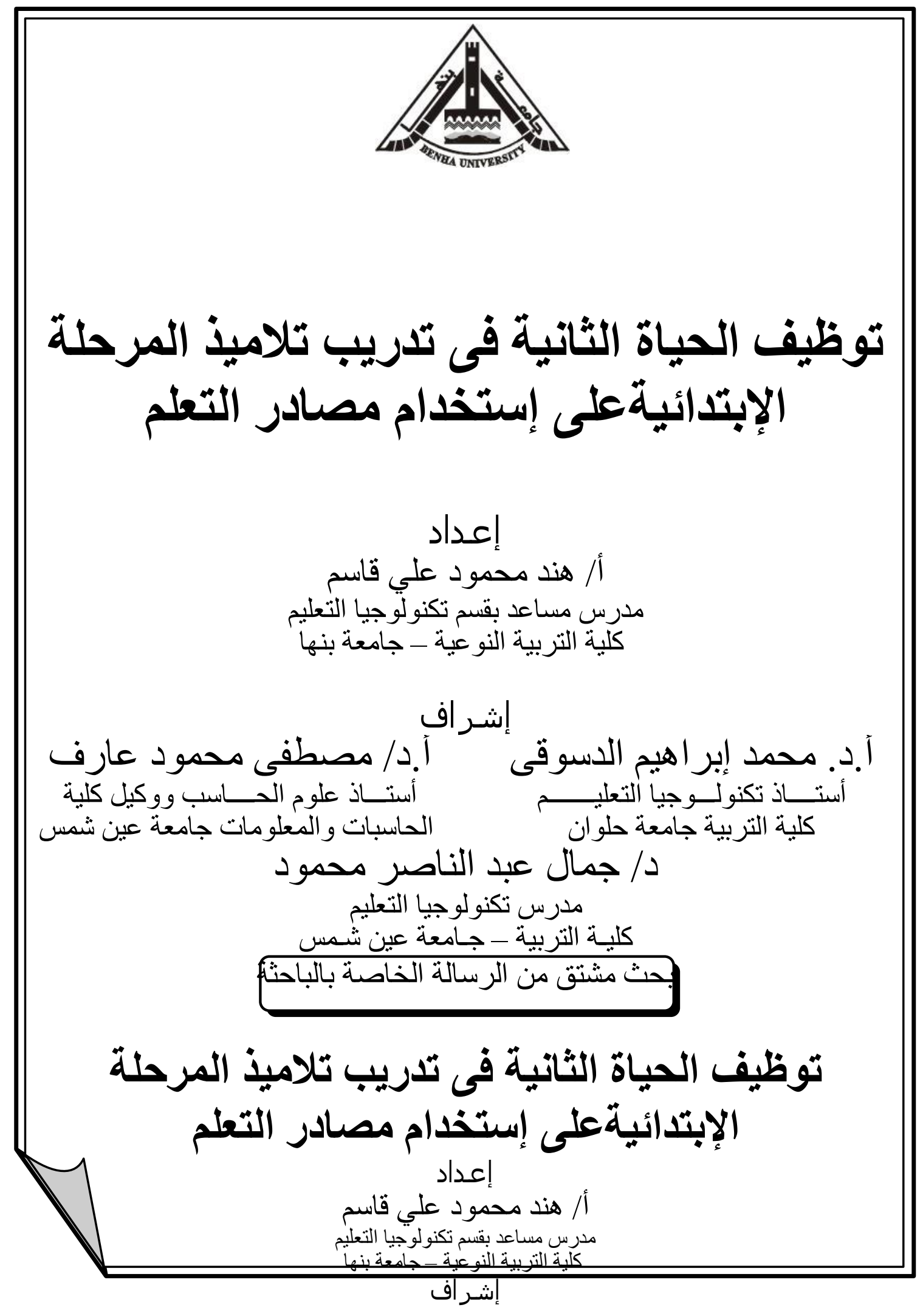




$$
\begin{aligned}
& \text { آ.د / مصطفى محمود عارف }
\end{aligned}
$$

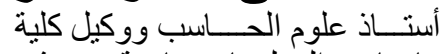

$$
\begin{aligned}
& \text { الحاسبات والمعلومات جامعة عين شمس لئ }
\end{aligned}
$$$$
\text { ا.د. محمد إبر اهيم الدسوقى }
$$

محمود

\section{مستخلـــص الدراســــة}

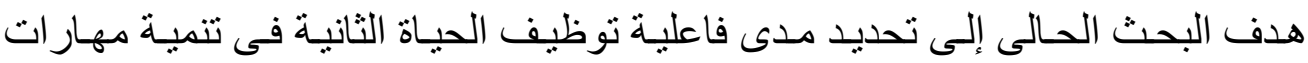

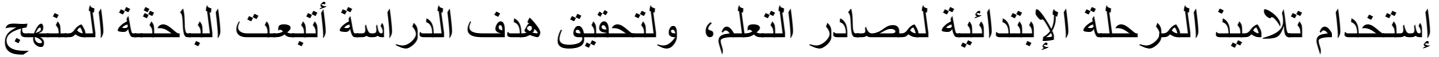

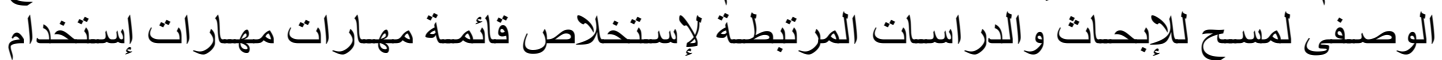

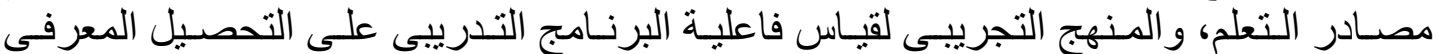

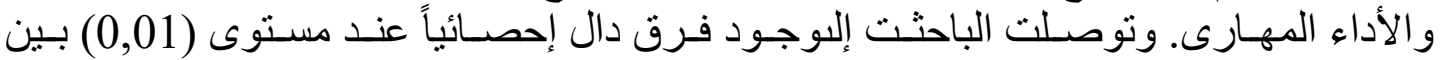

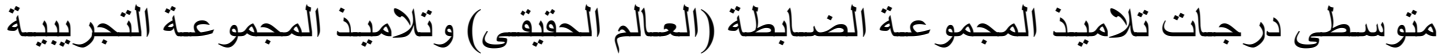
(الحياة الثانية) فى التحصيل المعرفى والأداء المهارى للتدريب على مهار ات إستخدام مصـادر التعلم لصالح المجمو عة التجريبية 
ا.د. محمد إبر اهيم، أ.د / مصطفى محمود،د / جمال عبد الناصر، أ/ توظيف الحياة الثانية فى تلريب تلاميذ المرحلة الإبتدائية

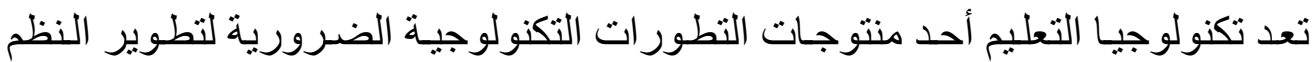

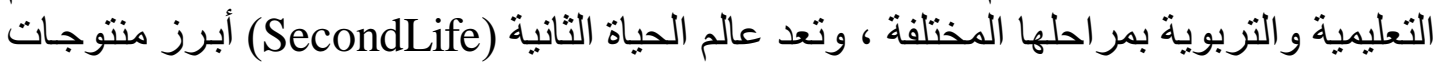

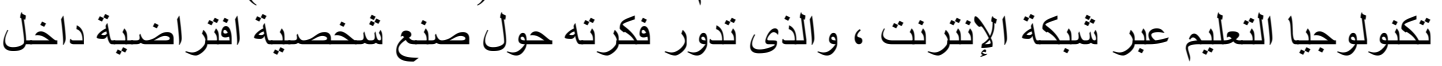

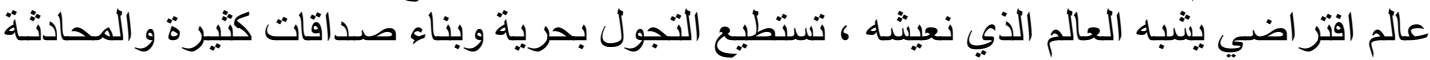

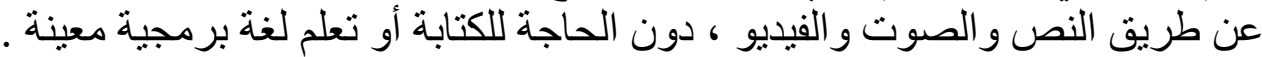

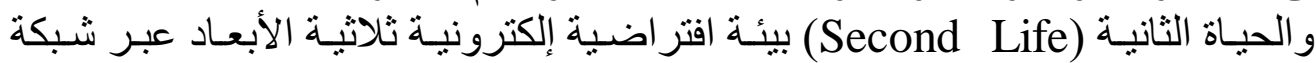

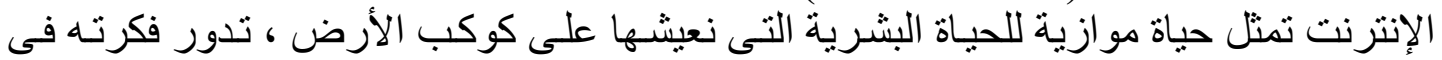

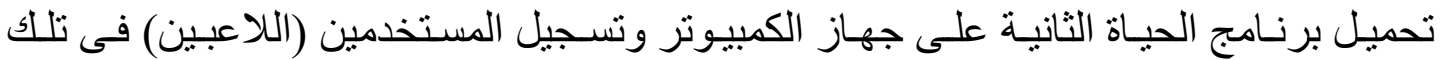

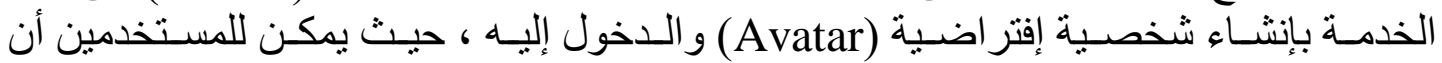

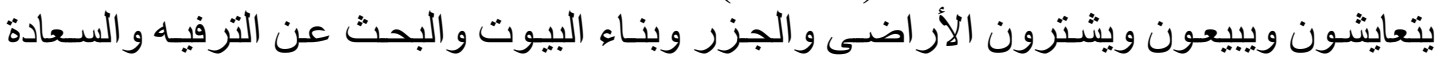

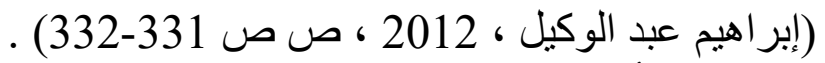

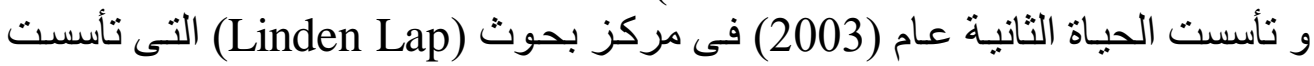

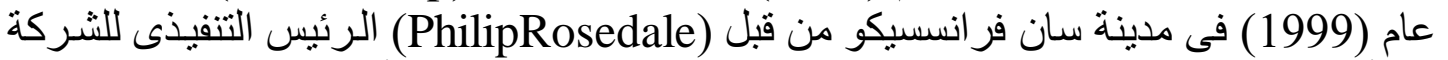

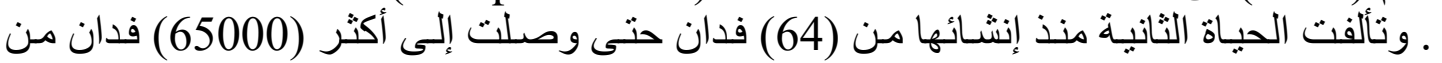

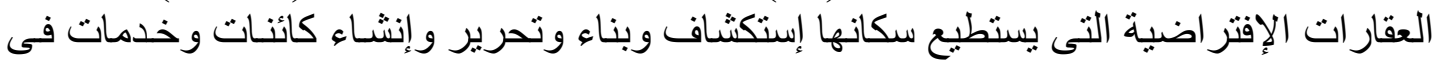

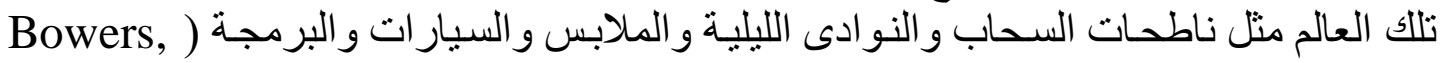
.(Ragas \& Neely, 2009, P P 40-50

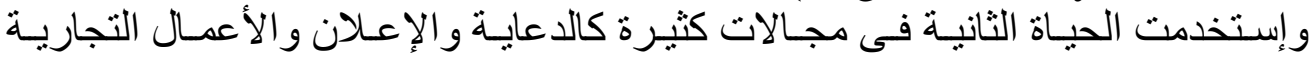

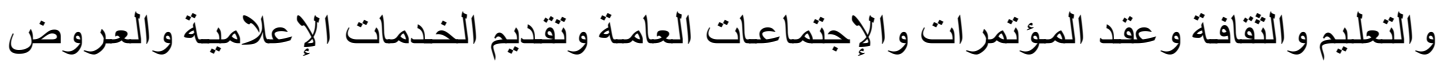

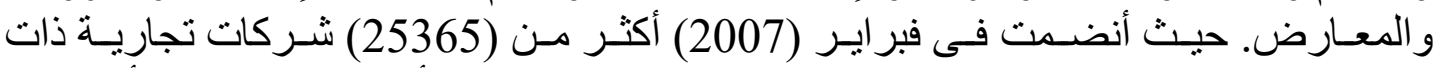

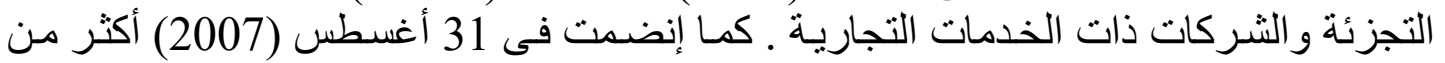

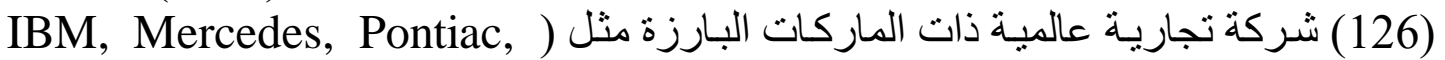
(Nissan, Dell, BMG ميسنجر(Messinger, Stroulia, Lyons, 2008, P P 1-18) إلى إنضمت اكثر من

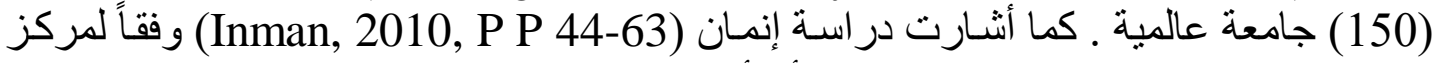
بحوث (Linden Lap) فى عام (2008) أن أكثر من (300) من الجامعات العالمية تعقد الكثير

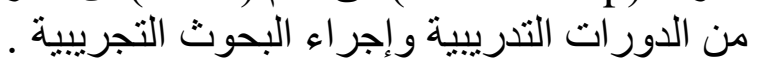

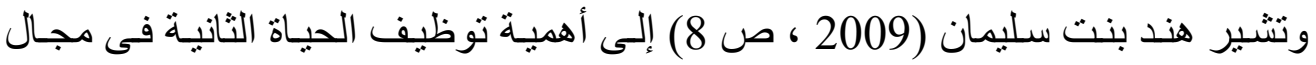

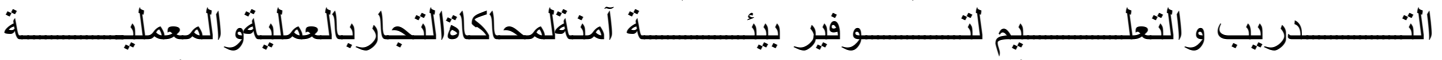

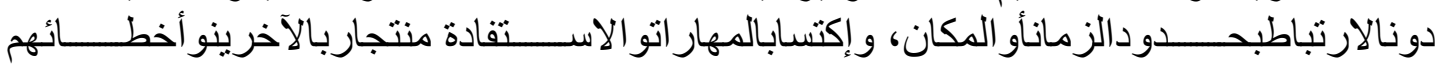

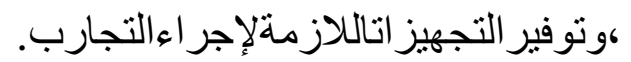

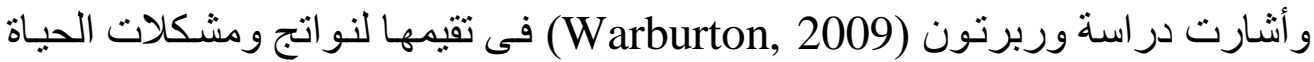

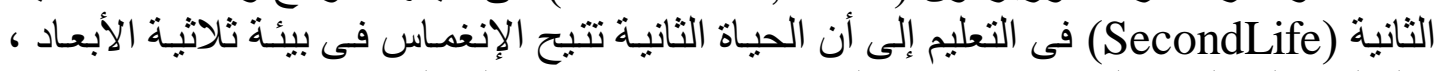
و التخلب على القيود المادية ، وتعزيز التعليم العلاقات الإجتماعية بين المتعلمين.

و أنتارت در اسـة وسترو لاند و آخرون ( Westmoreland, Ragas, \& Neely, (2009, p 212 فى تقييمها للحياة الثانية (SecondLife) كأحد نطبيقات العو الم الإفتر اضية 


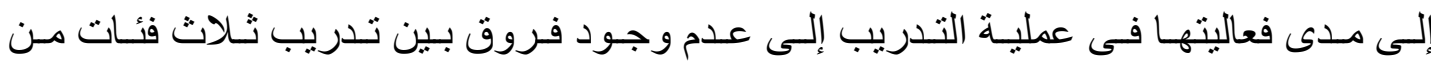

$$
\text { المجمو عات (المبتدئين ، متوسطى علئي الخبرة ، خبير ). }
$$

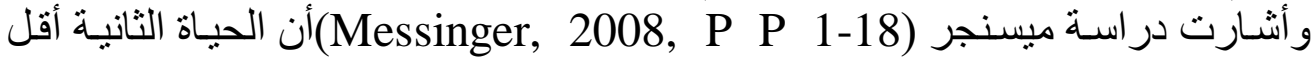

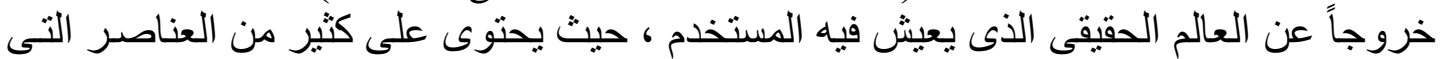

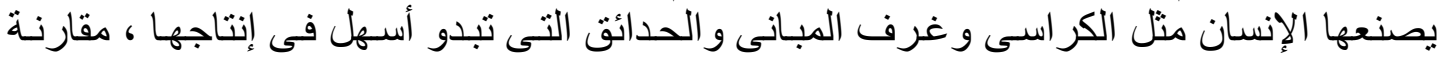

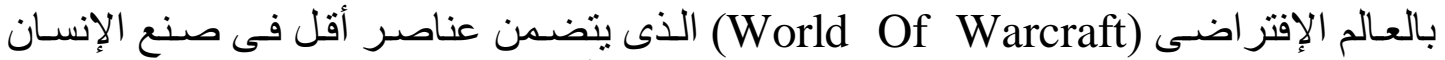

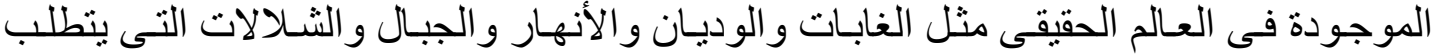
الكثير من الوقت فى إنتاج رسوماتها.

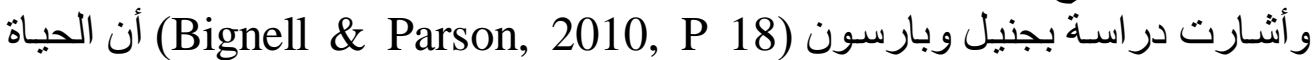

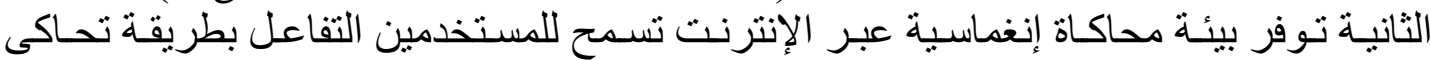

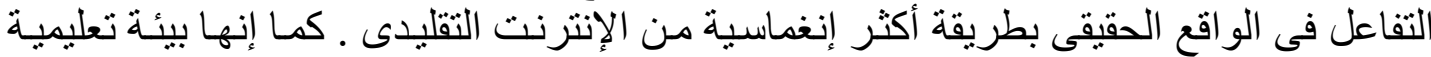

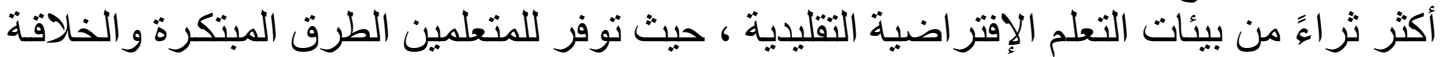

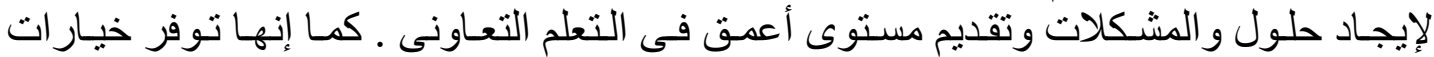

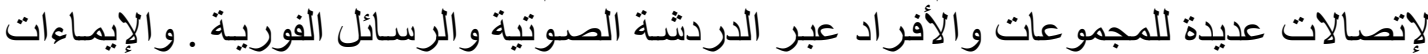

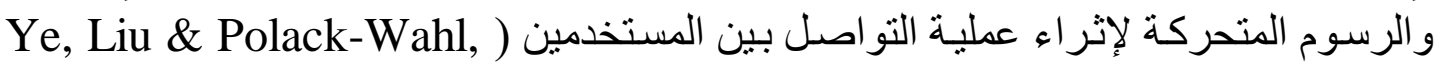
(2007, P 2

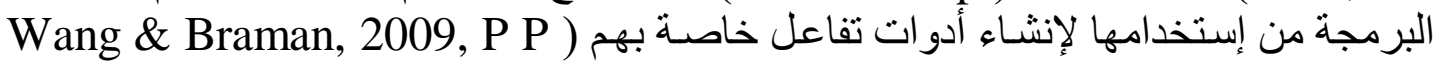

الأمر الذى جعل الحياة الثنانية أكثر العو الم الإفتراضية شعبية لدى المؤسسات التعليمية ،

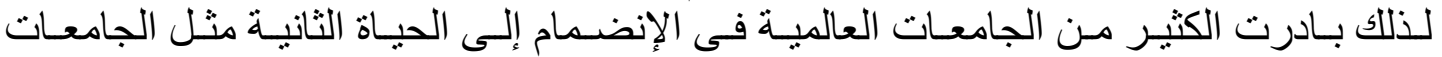

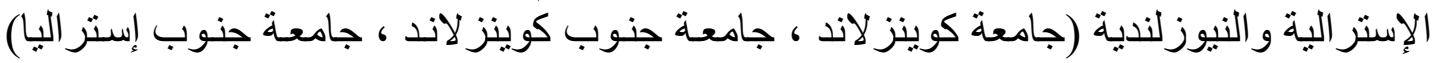
(Farley, 2011, P P 5-6) (InternationalSocietyforTechnologyinEducation (ISTE))

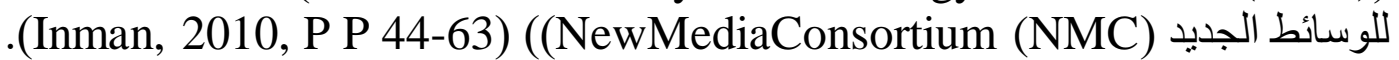

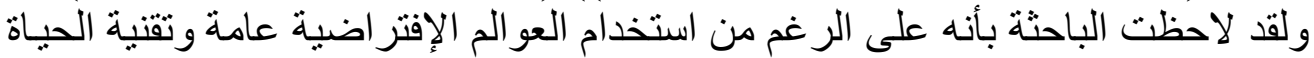

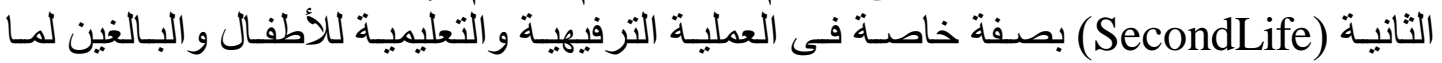

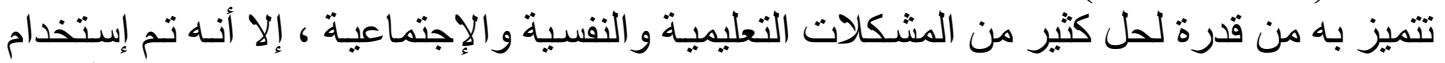

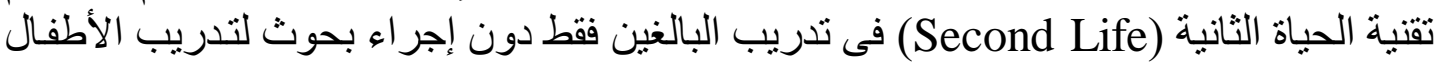

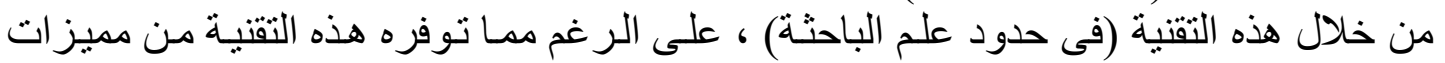

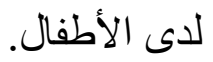

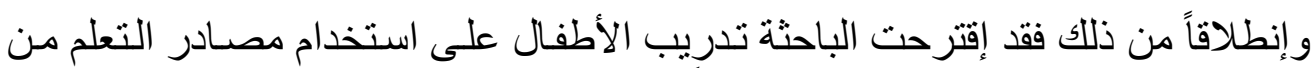

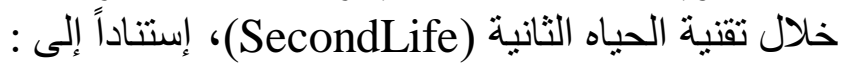

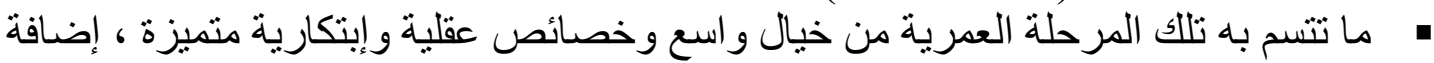

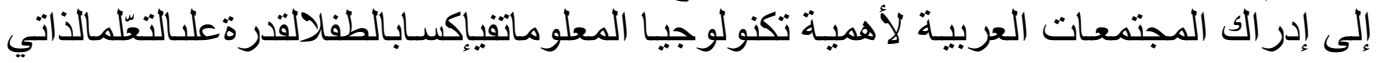

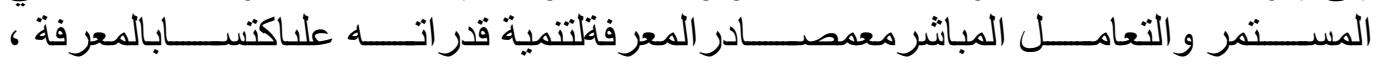

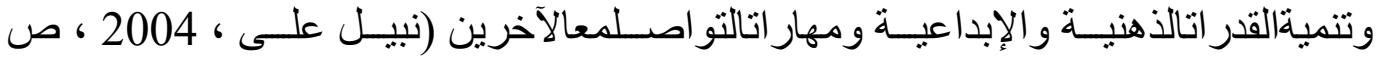

• مشـروع تطـوير وتنميـة الطفولـة المبكرة في جمهوريـة مصـر العربيـة (2003 - 2006) بالتعاون بين وزارة التربية والتعليم ومنظمة اليونسكو إلى أنه يجب على النى الأطفال أن يكونـوا 
ا.د. محمد إبر اهيم، أبد / مصطفى محمود،د / جمال عبد الناصر ، أ/ توظبف الحياة الثانية فى تدريب تلاميذ المرحلة الإبتدائية

قادرين على فهم طرق تشغيل الكمبيوتر واستخدام شبكة الإنترنت ، وكيفيـة استخلاله كأداة

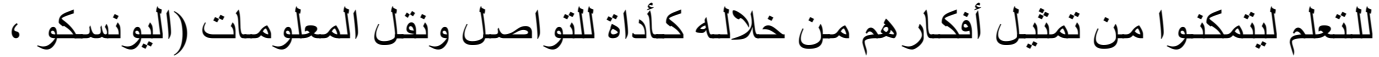

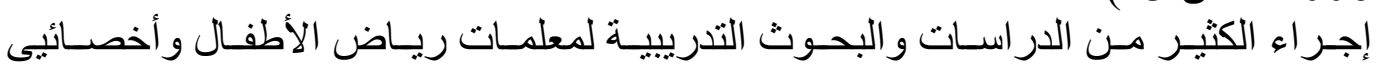

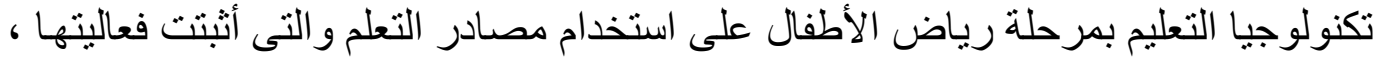

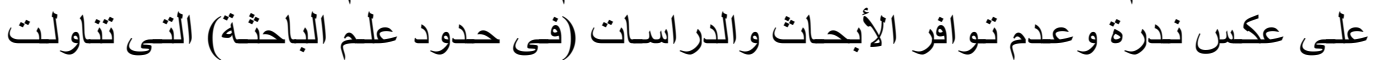

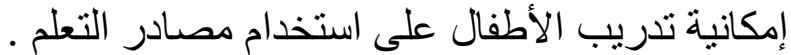

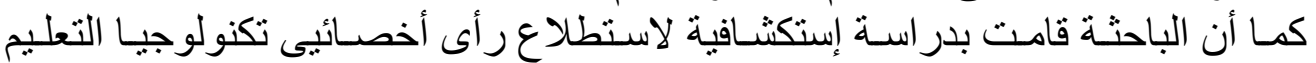
بالمرحلة الابتدائية بإدارة بنها التعليمية بمحافظة القليوبيـة لإبداء آر ائهم حول استخدام الأطفال

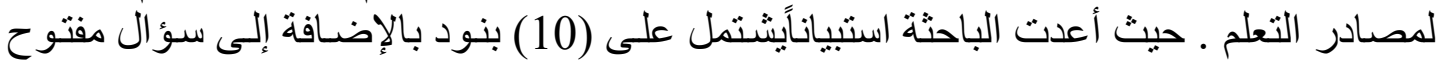

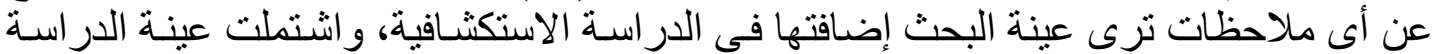

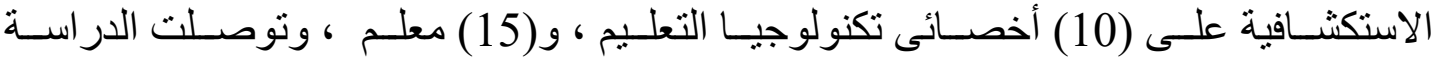

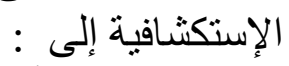

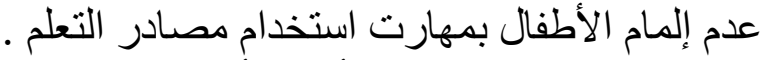

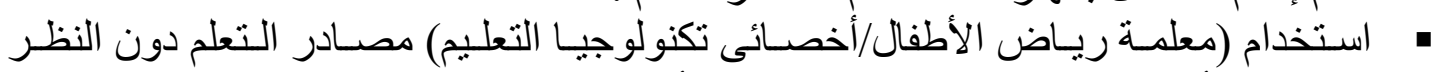

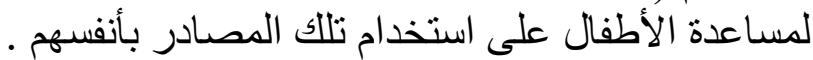

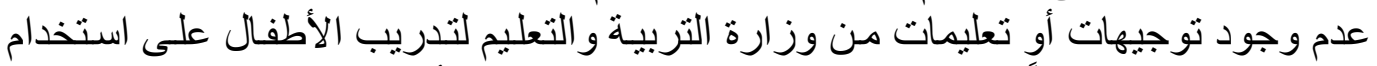

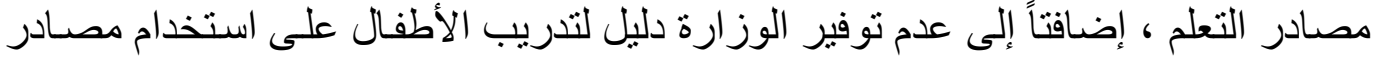

الإدارة المدرسية لا توفر تسهيلات لتدريب الأطفال على إستخدام مصادر التعلم .

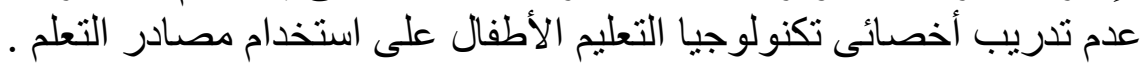

مشكلة البحث: وتساؤ لاتها

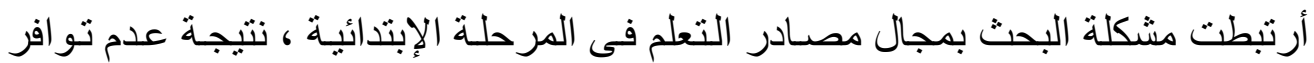

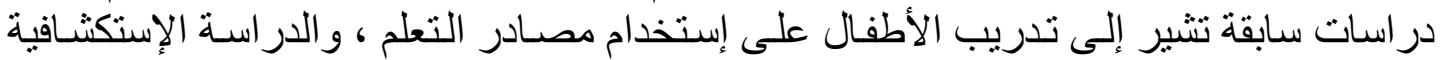

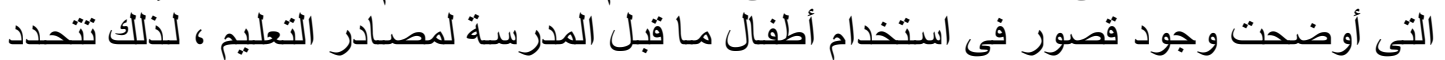

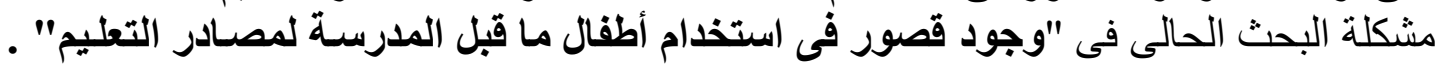

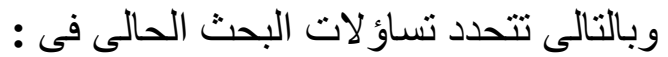

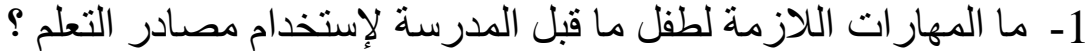

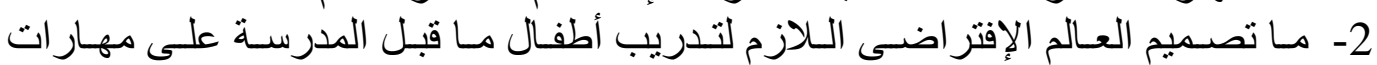

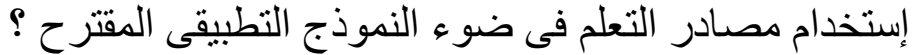

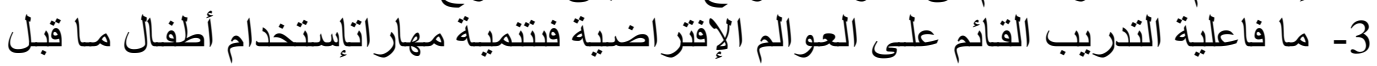
المدرسة لمصادر التعلم ؟ ملثة

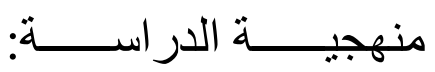

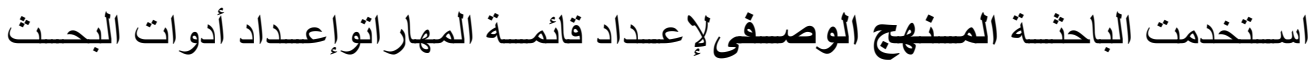

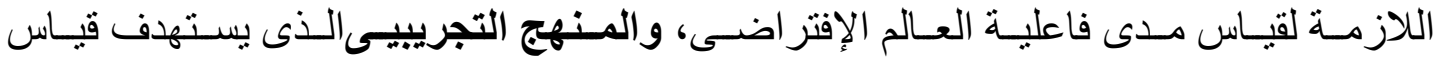

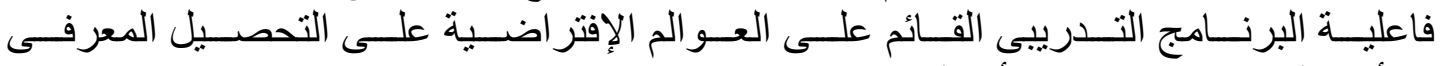
و الأداء المهارى لإستخدام الأطفال . لإن 


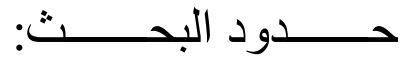 \\ يقتصر البحث الحالى على:}

• حدود مكانية: المدارس الابتدائية بمدينة بنها.

• حدود موضو عية: الأداء المعرفى والأداء المهارى لمهار ات إستخدام مصادر التعلم .

• حدود زمنية: الفصل الدر اسى الأول للعام الدراسى 2015 - 2016 ـ

تتمثل إجمالى عينة البحتفى عدد (40) طفل فى الصف الثالث في مدرسـة بنها الحديثة

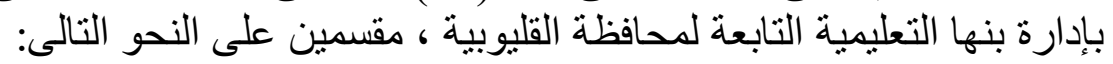

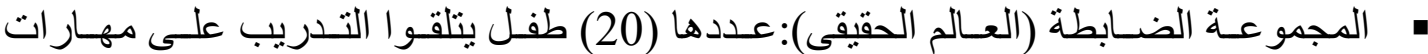

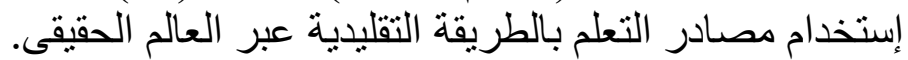

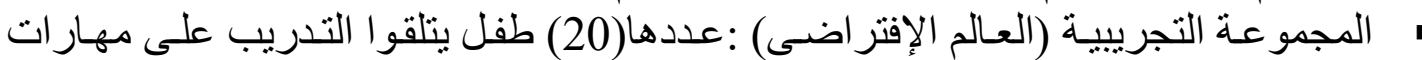
إستخدام مصادر التعلم بطريقة العالم الإفتر اضى عبر عالم الحياة الثانية (Second Life).

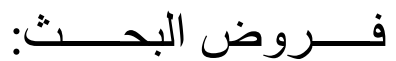

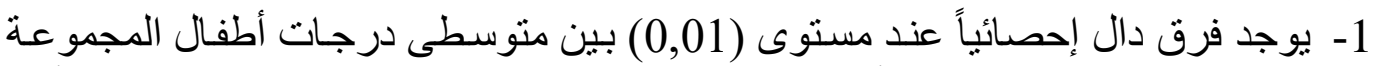

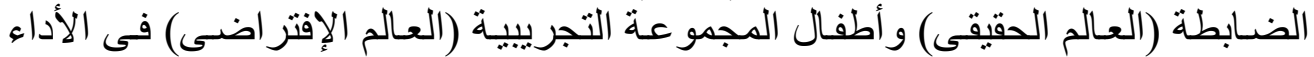

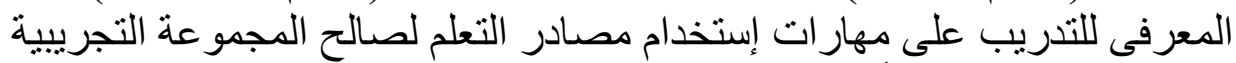

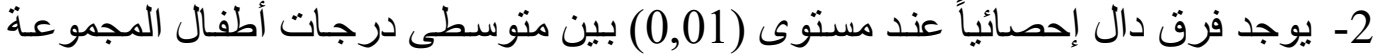

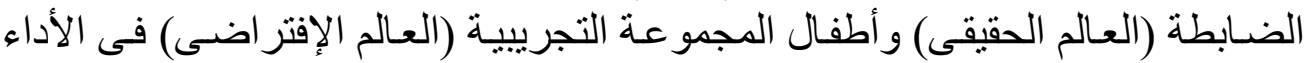

المهارى للتدريب على مهار ات إستخدام مصادر التعلم لصالح المجموعة التجريبية

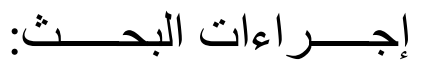

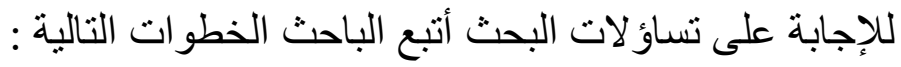

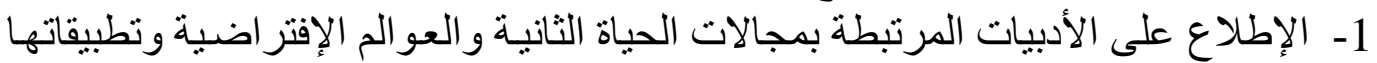

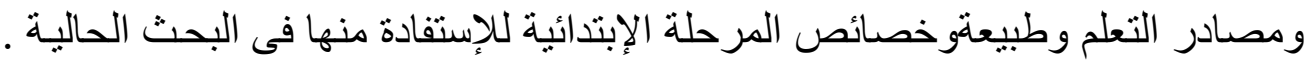

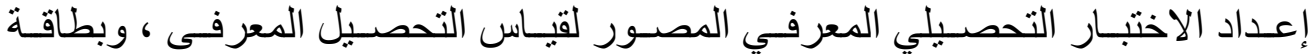

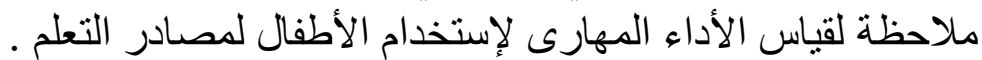

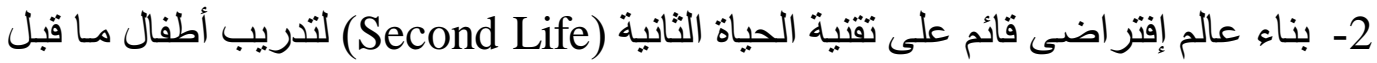

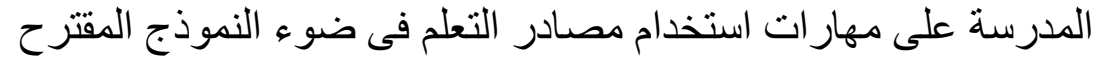

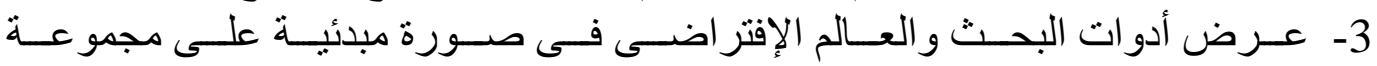

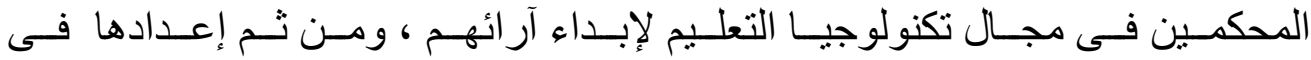
صورتها النهائية القابلة للتطبيق.

4- التطبيق القبلي للاختبار التحصيلي المصور وبطاقة الملاحظة على عينة البحث. 5- تطبيق مادة المعالجة التجريبية على عينة البحث. 6- التطبيق البعدى للاختبار التحصيلي المصور وبطاقة الملاحظة على عينة البحثة.

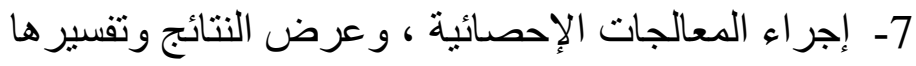


ا.د. محمد إير اهيم، أبد / مصطفى محمود،د / جمال عبد الناصر ، أ/ توظيف الحياة الثانية فى تدريب تلاميذ المرحلة الإبتدائية المرجة

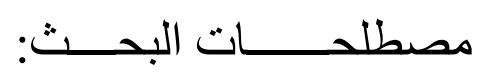

الحياة الثانية(Second Life):

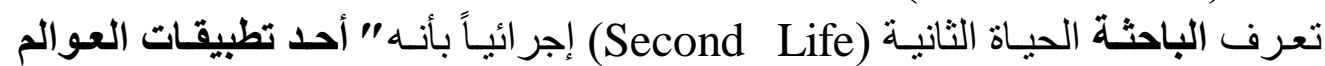

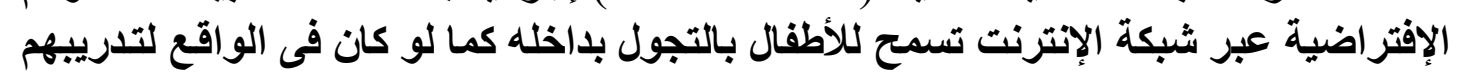

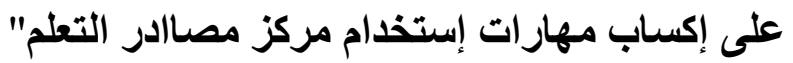

التـــدريـب (Training)

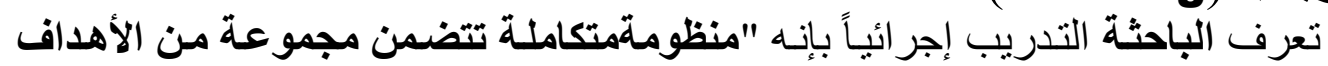

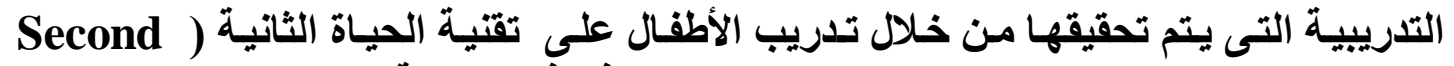

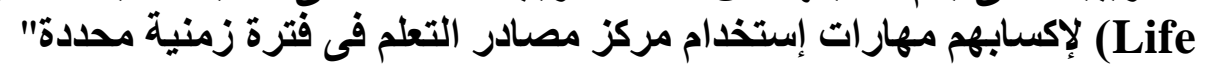

مصادر التعلم (Learning Resource):

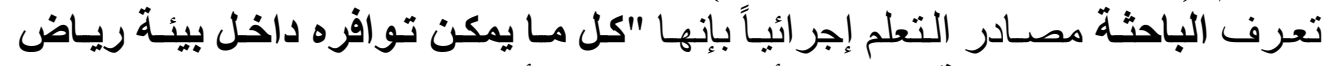

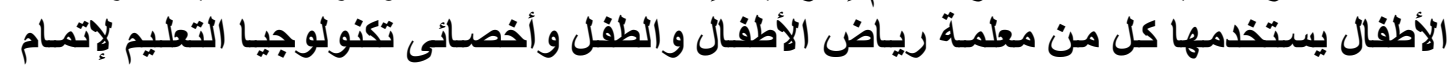

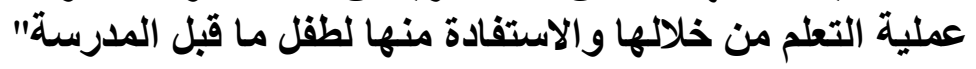

$$
\text { أدوات البحـــــثـ: }
$$

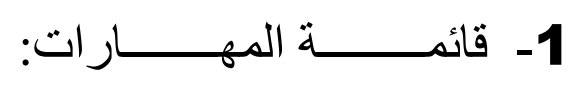

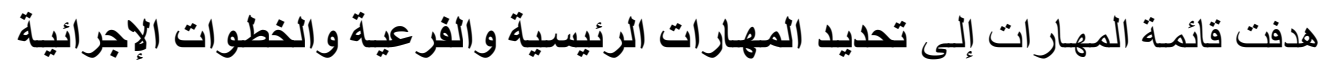

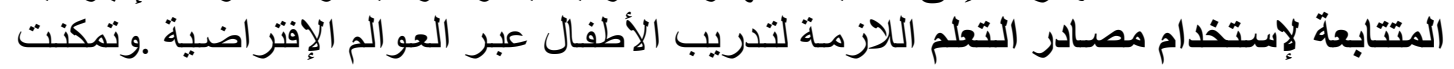

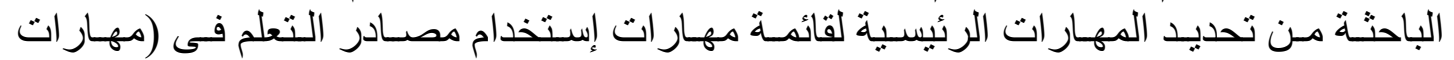

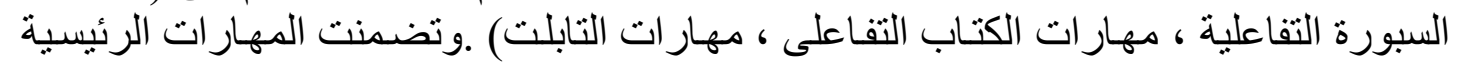
عدد (39) من المهار ات الفئرة الفرعية.

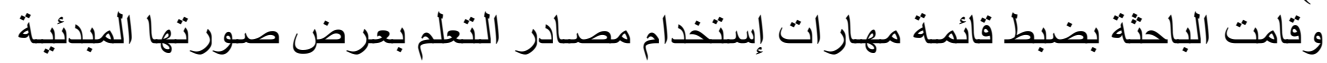

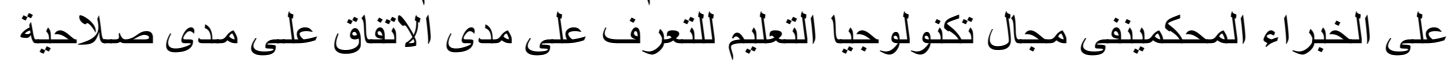
قائمة المهارات ، وقد توصلت إلى نسب الاتفاق بين خبر اء تكنولو جيا التعليم إلى (94,26٪)

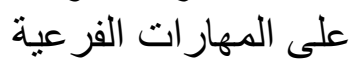

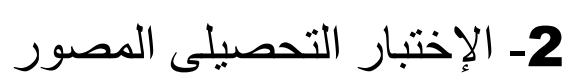

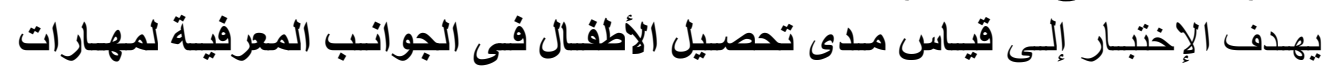

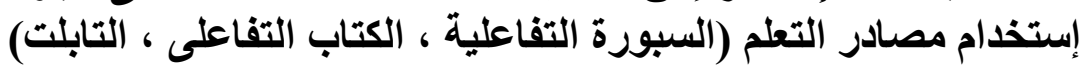

$$
\text { أ) صدق الإختبار التحصيلى المصور: }
$$

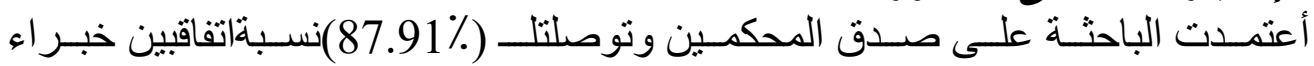
تكنولوجيا التعليم إلى على مفردات الإختبار التحصيلى المصورد. 
ب) ثبات الإختبار التحصيلى المصور: أعتمدت الباحثة على حساب الثبات باستخدام طريقة ألفا كرونباخ وتوصلت معامل ثبات (91,74) و هذا يدل على أن المقياس يتمتع بدرجة ثبات الثبات عالية جداً.

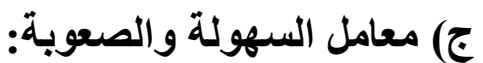

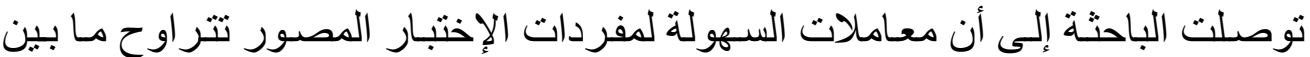

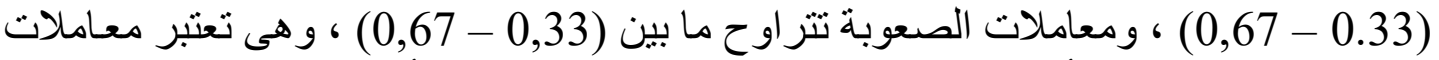

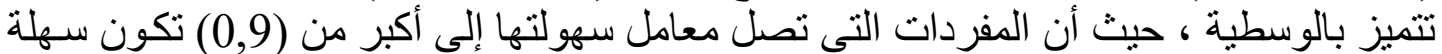

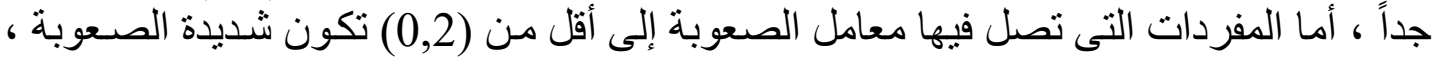

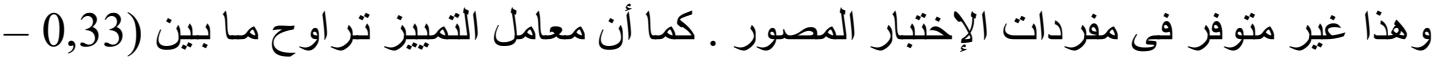
0,83) ، وهى تعتبر معاملات تمييز مقبولة لإنها لا تقل عن (0,2) وقريبة من الو احس الصد الصحيح

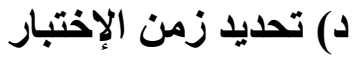

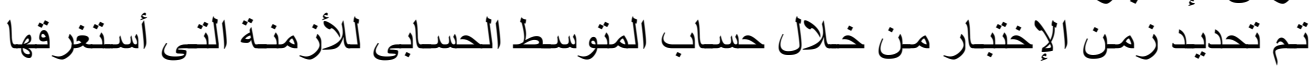

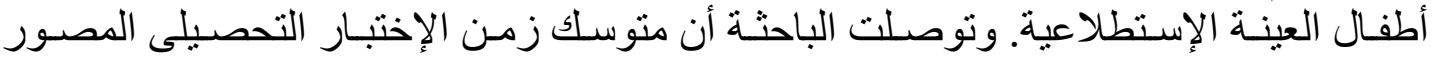

(30) دقيقة.

\section{3- بطــــــــة المــلاحظــــــة}

هدفت بطاقة الملاحظة إلى قياس مدى تحصيل الأطفال فى الجوانب الأدائية لمهارات إستخدام مصادر التعلم (السبورة التفاعلية ، الكتاب التفاعلى ، التابلت) .

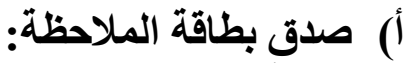

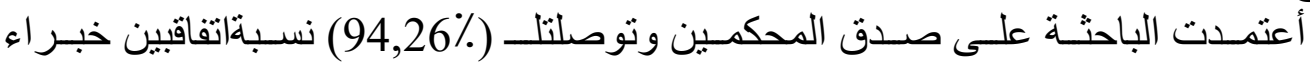
تكنولوجيا التعليم إلى على مفردات الإختى إنبار التحصيلى المصور

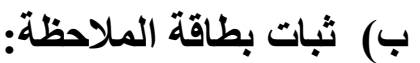

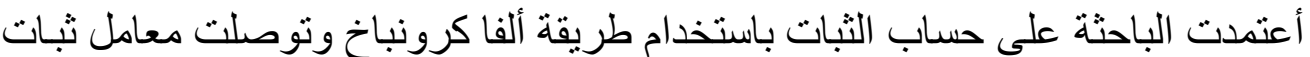
(89,53\%)و هذا يدل على أن المقياس ينتع بدرجة ثبات عالية جداً.

$$
\text { نتــــائســـ البحـــثـ: }
$$

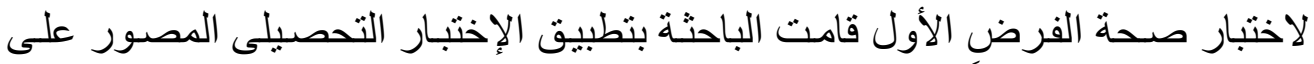

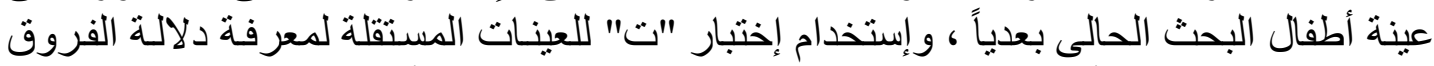

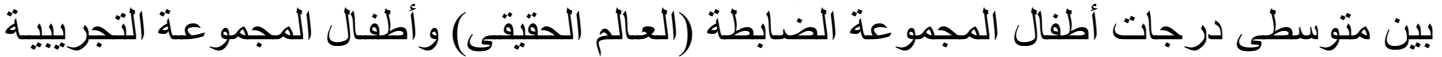

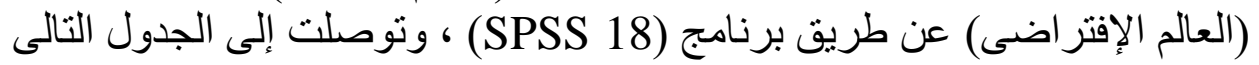

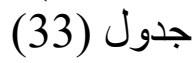

إختبار "ت" لدلالة الفروق بين منوسطى المجمو عة الضابطة و المجمو عة الإنة

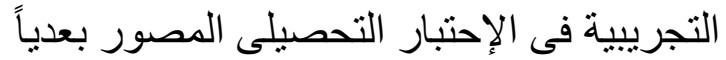

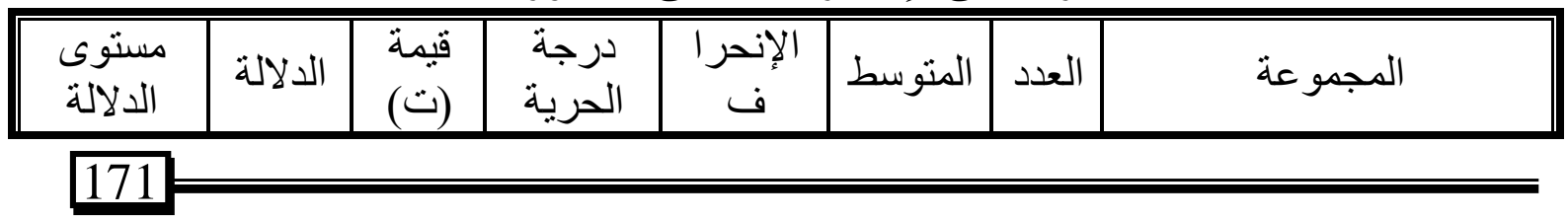


ا.د. محمد إير اهيم، أبد / مصطفى محمود،د / جمال عبد الناصر ، أ/ توظيف الحياة الثانية فى تدريب تلاميذ المرحلة الإبتدائية

\begin{tabular}{|c|c|c|c|c|c|c|c|}
\hline & & & & المعيار & & & \\
\hline \multirow{2}{*}{ دالة عند } & \multirow{2}{*}{0,000} & \multirow{2}{*}{$\begin{array}{c}15,05 \\
7\end{array}$} & \multirow{2}{*}{38} & 1,309 & 8,25 & 20 & المجمو عة الضابطة الحقيقى) \\
\hline & & & & 1,538 & 15,45 & 20 & (العالم الإفتر اضلىي) \\
\hline
\end{tabular}

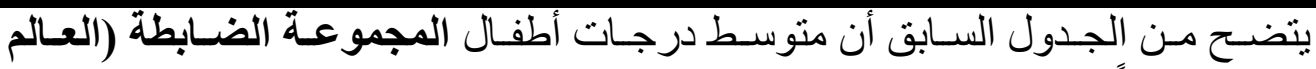

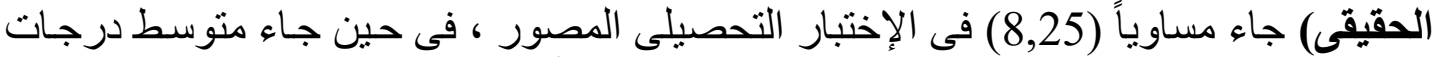

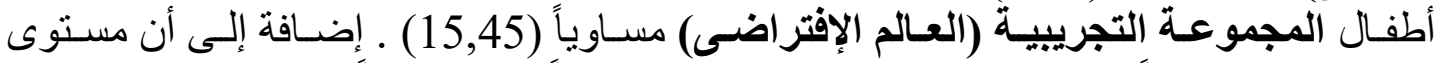

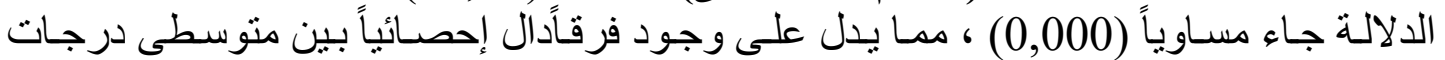

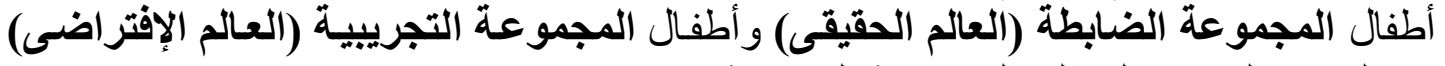

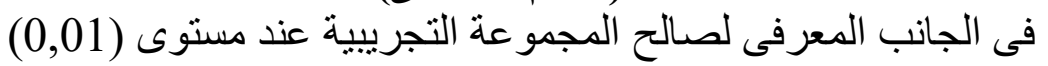
الفرض الثانى للبحث:

لاختبار صحة الفرض الثانى قامت الباحثة بتطبيق بطاقة الملاحظة على على عينـة أطفال

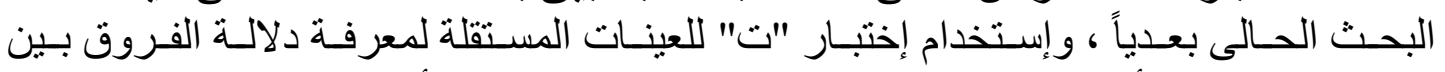

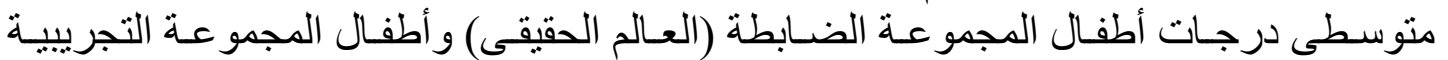

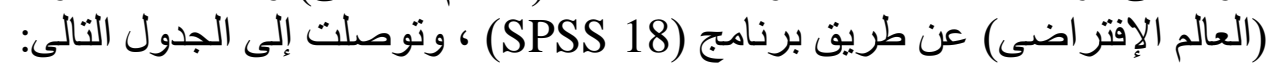

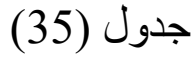

إختبار "ت" لدلالة الفروق بين متوسطى المجموعة الضابطة و المجمو عة التجريبية فى بطاقة الملاحظة بعدياً

\begin{tabular}{|c|c|c|c|c|c|c|c|c|}
\hline مستوى الدلالة & الدلالة & قيمة & الحرية & الإنحر| & طنو & العدد & المجمو عة & المهار ا \\
\hline \multirow{2}{*}{ دالة عند } & \multirow[b]{2}{*}{0,000} & \multirow[b]{2}{*}{4,339} & \multirow[b]{2}{*}{38} & 1,309 & 13,35 & 20 & المجمو عة الضابطة الحقيقى) & \multirow{2}{*}{ التفاعلية } \\
\hline & & & & 1,525 & 15,30 & 20 & 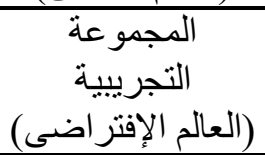 & \\
\hline \multirow{2}{*}{ دالة عند } & \multirow[b]{2}{*}{0,000} & \multirow[b]{2}{*}{6,148} & \multirow[b]{2}{*}{38} & 1,395 & 10,55 & 20 & المجمو عة الضابطة & \multirow{2}{*}{ التفاعلى } \\
\hline & & & & 1,050 & 12,95 & 20 & 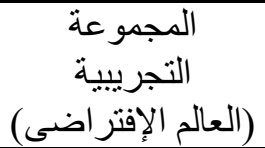 & \\
\hline \multirow{2}{*}{ دالة عند } & \multirow[b]{2}{*}{0,000} & \multirow[b]{2}{*}{8,023} & \multirow[b]{2}{*}{38} & 1,071 & 13,10 & 20 & المجمو عة الضابطة & \multirow[b]{2}{*}{ التابلت } \\
\hline & & & & 1,461 & 16,35 & 20 & 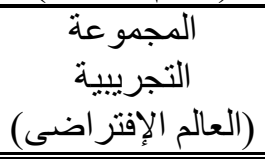 & \\
\hline
\end{tabular}




\begin{tabular}{|c|c|c|c|c|c|c|c|c|}
\hline \multirow{2}{*}{ مستوى عند } & \multirow[b]{2}{*}{0,000} & \multirow{2}{*}{$\begin{array}{c}10,95 \\
8\end{array}$} & \multirow[b]{2}{*}{38} & 2,248 & 37 & 20 & المجمو عة الضـابطة & \multirow{2}{*}{ الملاحظة } \\
\hline & & & & 2,137 & 44,60 & 20 & 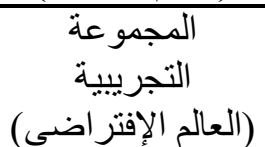 & \\
\hline
\end{tabular}

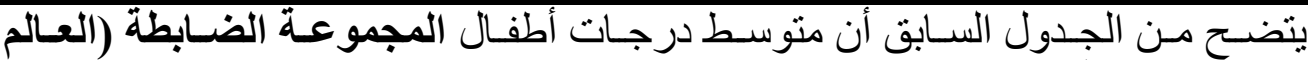

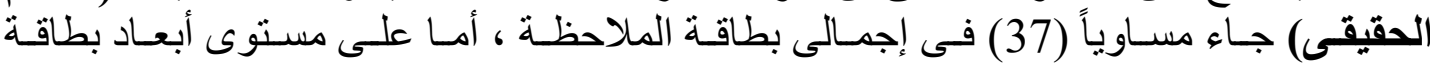

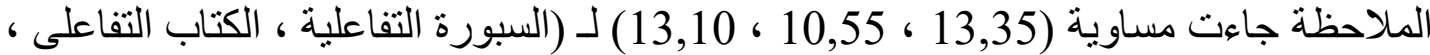

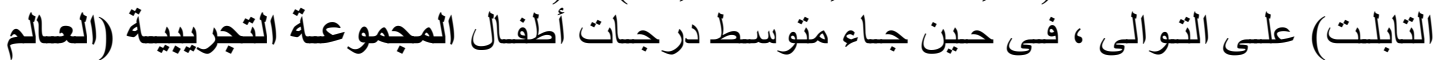

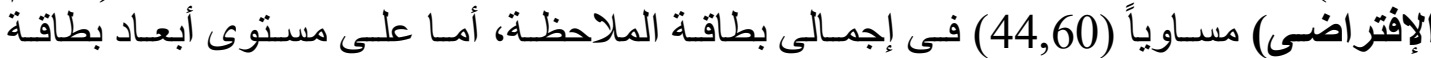

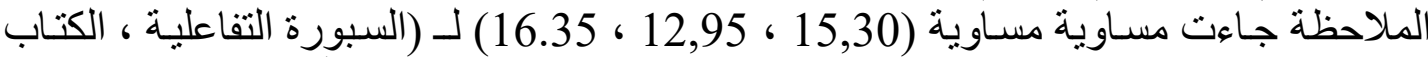

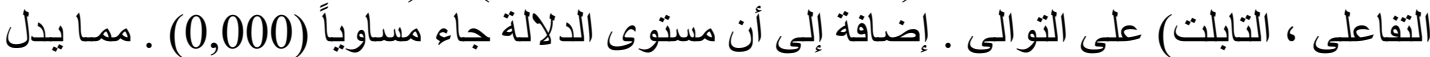

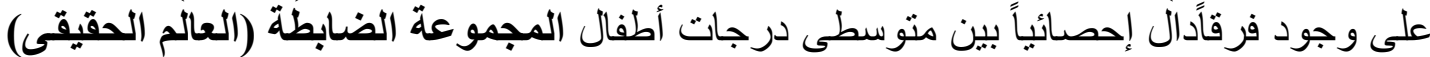

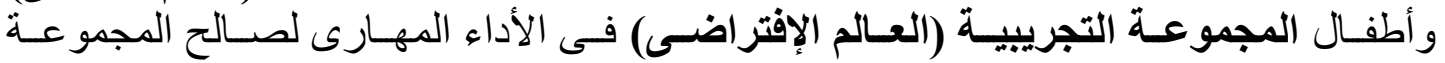
التجريبية عند مستوى (0,01)

$$
\text { تفسير نتائج الفرض الأول و الثانى للبحث . }
$$

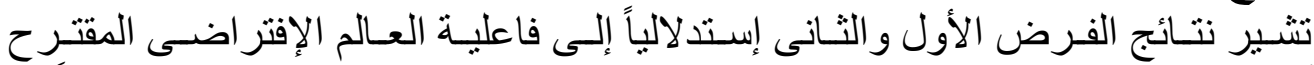

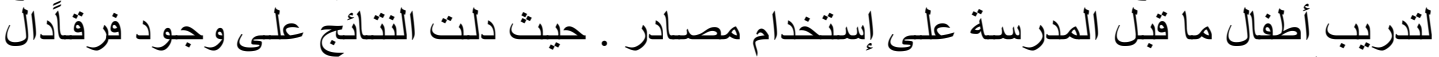

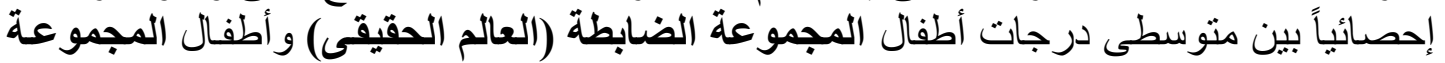

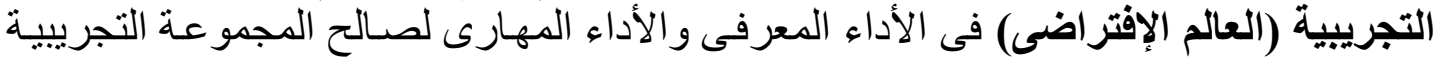

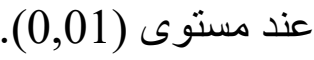

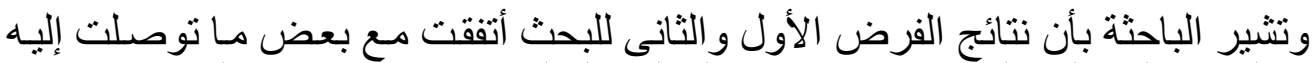

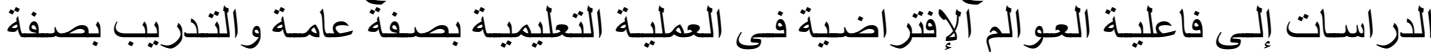

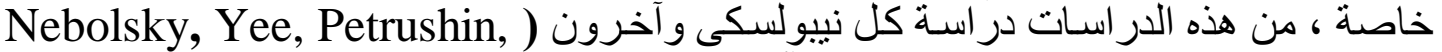
Ye, Liu \& Polack-Wahi, 2007, P ) ،ي وآخرون (Gershman, 2004, PP31-36

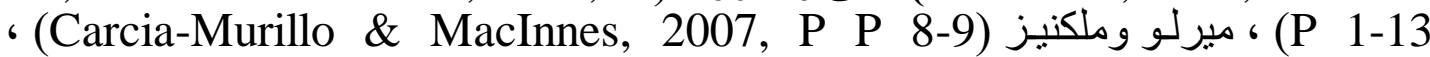
جاكسون وآخرون (Jackson, Gauntlet \& El Jeanette, 2008) ، فرنيس ( Kluge \& Riley, 2008, P ) (2008, P 1

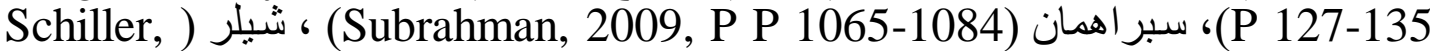

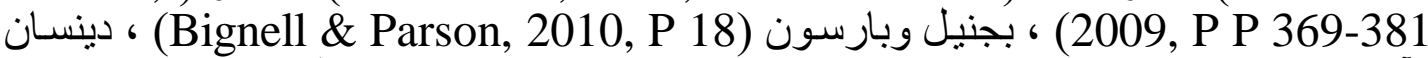
وآخرون (Duncan, Miller \& Jiang, 2012, P 11)، محمد سعد الدين(2012) ، (2012) ، مروة دربان حسن (2012) ، شونهيم وأخرون (Schoonheim, Heyden, Wiecha, 2014) ، كريك (207) ، (Kruk, 2014, P P 52-67) وترجع الباحثة فاعلية العالم الإفتر اضى المقتر حلتدريب أطفال ما قبل المدرسة على إستخدام مصادر إلىى:

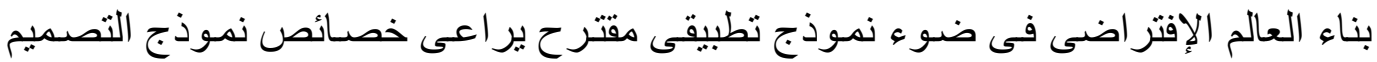

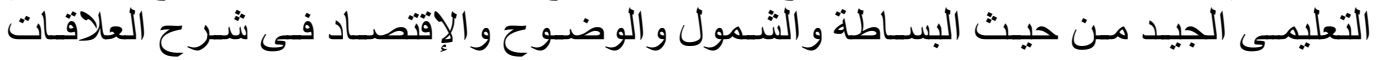
و العمليات و الإتساق الداخلى بين مكوناته ، حيث: 
ا.د. محمد إبر اهيم، أ.د / مصطفى محمود،د / جمال عبد الناصر، أ/ ت توظيف الحياة الثانية فى تدريب تلاميذ المرحلة الإبتدائية

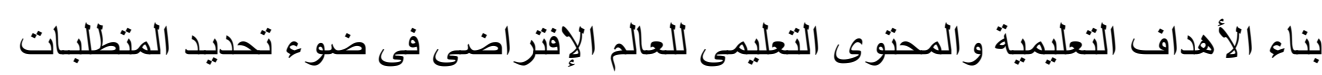

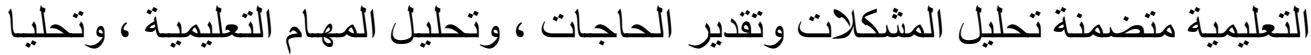

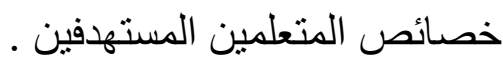

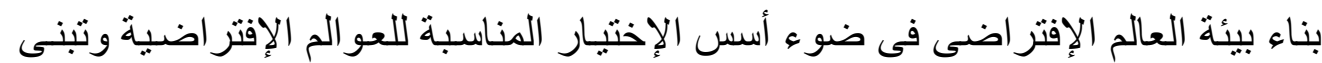

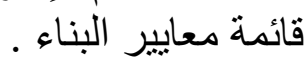

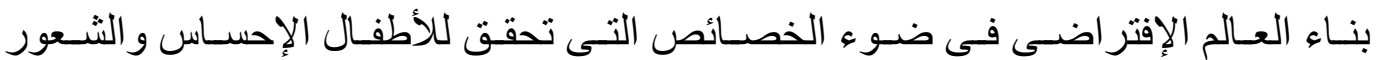

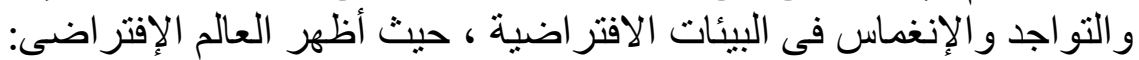

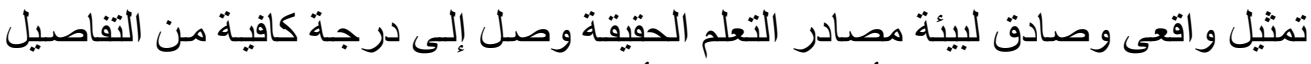

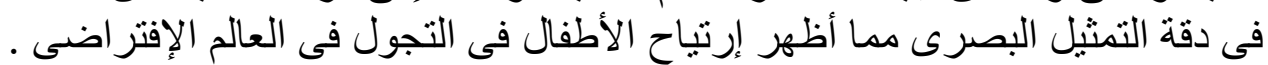

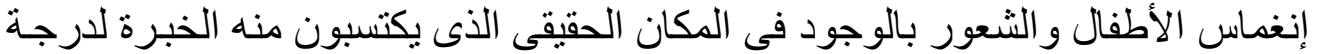

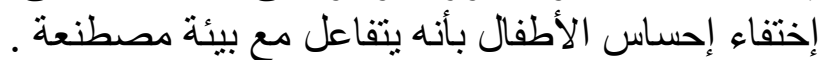

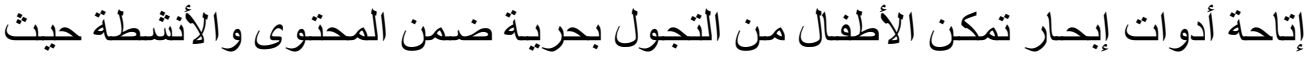

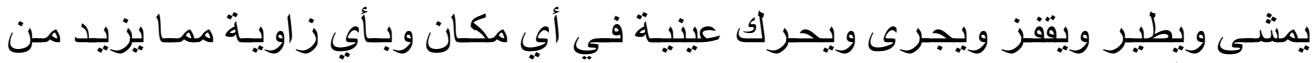

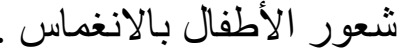

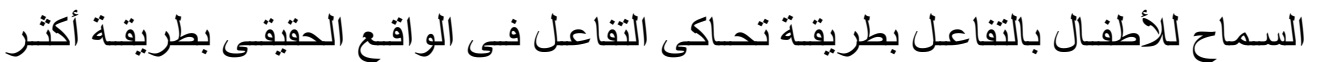

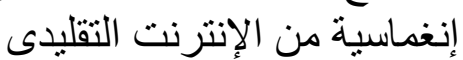

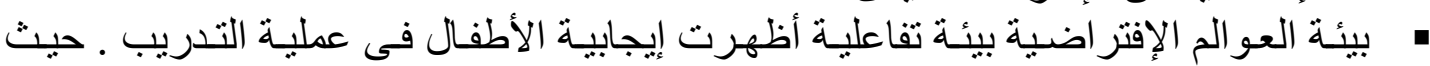

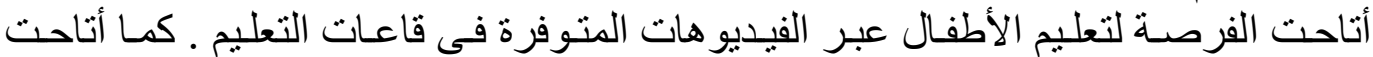

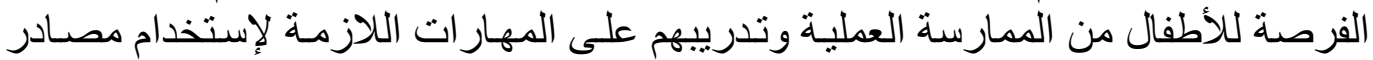

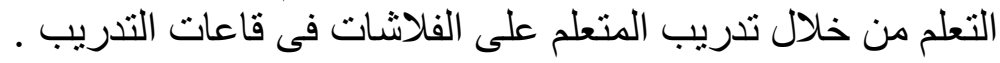




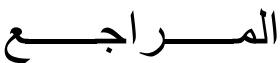

$$
\begin{aligned}
& \text { • إبر اهيم عبد الوكيل الفار(2012). تربويـات تكنولوجيـا القرن الحادى و العشرين: تكنولوجيـا }
\end{aligned}
$$

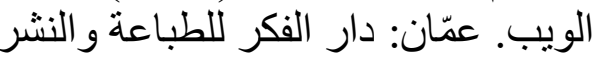

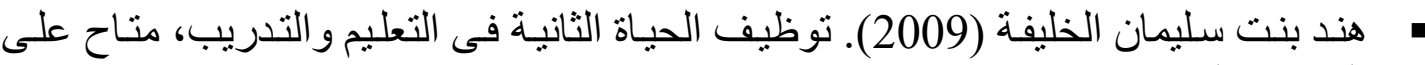

$$
\begin{aligned}
& \text { http://www.abegs.org/sites/Upload/DocLib3 الموقع الإلكترونى النى }
\end{aligned}
$$

- Bignell, S. \& Parson, V. (2010, Jan). Best Practices In Virtual Worlds Teaching : A Guide To using Problem-Based learning In Second Life. Project Present on University Of Derby, University Of Aston, The Higher Education Academy Psychology Network.

- Bowers, K., Ragas, M . \& Neely, J. (2009). Assessing the Value of Virtual Worlds for Post-Secondary Instructors: A Survey of Innovators, Early Adopters and the Early Majority in Second Life. International Journal of Humanities and Social Sciences, 3(1), 40-50.

- Farley, Helen. (2011, Dec 4-7). Recent developments in virtual worlds and their potential impact on their use in higher education. Australian Society for Computers in Learning in Tertiary Education, Wellington, New Zealand.

- Messinger, P., Stroulia, E. \& Lyons, K. (2008, July). A Typology of Virtual Worlds.

- Warburton, S. (2009) . Second Life in higher education: Assessing the potential for and the barriers to deploying virtual worlds in learning and teaching. British Journal of Educational Technology, 40(3), 414-426.

- Wang, Y. \& Braman, J. (2009) . Extending the Classroom through Second Life. Journal of Information Systems Education, 20(2), 235-248.

- Westmoreland, K., Ragas, M., \& Neely, J. (2009). Assessing the Value of Virtual Worlds for Post-Secondary Instructors: A Survey of Innovators, Early Adopters and the Early Majority in Second Life, International Journal of Humanities and Social Sciences, 3(1), 40-50.

- Ye, E., Liu, C. \& Polack-Wahl, H. (2007, Oct 10-13) . Enhancing Software Engineering Education Using Teaching Aids in 3-D Online Virtual Worlds. $37^{\text {th }}$ ASEE/IEEE Frontiers in Education Conference, 8-13. 